\title{
Expressão linguística e a produção escrita de surdocegos
}

\author{
Linguistic expression and written form production of \\ deafblind
}

\author{
Fatima Ali Abdalah Abdel CADER-NASCIMENTO \\ Centro Universitário do Distrito Federal (UDF)
}

\author{
Enilde FAULSTICH \\ Universidade de Brasília (UnB)
}

\begin{abstract}
RESUMO: O objetivo principal deste trabalho é relacionar a expressão linguística ao registro escrito de pessoas surdocegas. Discutimos as possibilidades de expressão linguística segundo a condição sensorial de surdocegos na relação com a produção textual. O corpus de análise é uma seleção de cinco trechos de textos produzidos por surdocegos. A metodologia seguiu os procedimentos: i) descrição, de modo breve, das possibilidades de expressão linguística dos surdocegos, segundo o perfil sensorial e linguístico; e ii) descrição da forma de expressão linguística, com trechos comentados de textos produzidos por surdocegos. Os resultados evidenciaram a importância do contato de surdocegos com textos escritos no código braille ou no sistema ampliado, o que viabiliza a aprendizagem acidental de estruturas textuais e a ampliação do vocabulário. Percebemos que a falta do contato direto com o texto altera o padrão de acesso à língua portuguesa na modalidade escrita. Os dados mostraram a interferência da expressão linguística no registro escrito, sendo que o texto de surdocegos, usuários de língua de sinais, aproxima-se da produção escrita de surdos. Concluímos que, independentemente da condição sensorial e linguística dos surdocegos, todos demandam atendimento complementar em português como segunda língua.
\end{abstract}

PALAVRAS-CHAVE: Português do Brasil. Surdocegueira. Língua de sinais háptica.

ABSTRACT: The main aim of this paper is to make a connection between linguistic expression to the written form production of deafblind people. We discuss linguistic expression possibilities according to deafblind sensorial conditions in relation of text production. The corpus of the analysis was a selection of five excerpts produced by deafblind individuals. The methodology followed these procedures: i) summarized description of possible linguistic expressions of deafblind individuals, according to the sensory and linguistic profile; and ii) description of linguistic expression with comments on the excerpts produced by deafblind people. Results showed the importance of deafblind individuals being in contact with written texts in braile or to the amplified system, which makes way to acquired learning of textual structure and amplified vocabulary. We noticed that the lack of direc t contact with the text changes the pattern of access to written Portuguese. Data showed the interference of lin guistic expressions in written form, for the text deafblind sign language users produce is similar to the written production of deaf individuals. Finally, we came to the conclusion that despite sensorial and linguistic condition of deafblind people, all of them require additional monitoring of Portuguese as L2.

KEYWORDS: Brazilian Portuguese. Deafblind. Haptic sign language 


\section{Introdução}

A natureza e a extensão do termo surdocegueira podem desencadear interpretações equivocadas, uma vez que o termo em si gera uma compreensão da ausência total da recepção de informações pela via auditiva e visual. A combinação dos distintos graus de surdez com as variações clínicas e funcionais próprias da deficiência visual pode, todavia, ocorrer na mesma pessoa. O sentido do termo surdocegueira, de fato, envolve a descrição e a combinação das distintas variações nos graus de surdez, assim como comprometimento visual, e ambos conduzem a comportamentos e desempenhos linguísticos diferenciados. Cader-Nascimento e Costa (2010, p.18) demonstram que as implicações da condição sensorial e linguística na surdocegueira podem “[...] acarretar sérios problemas de comunicação, mobilidade, informação e, consequentemente, provocar a estimulação e atendimentos educacionais específicos". Seguindo este raciocínio, a surdocegueira interfere nos processos de aquisição acidental, por meio da imitação e da observação, da linguagem, do desempenho e dos comportamentos sociais.

Aliada a estas implicações, está a mais significativa, do ponto de vista do desenvolvimento humano, que é a alteração no processo de aprendizagem dos signos criados pela sociedade, entre eles: a linguagem, a escrita, o sistema de números e a estrutura conceitual que permeiam as interações sociais. Ao considerar que a linguagem é o substrato do pensamento, a surdocegueira altera a recepção de informação pelos sentidos distais, que são a audição e a visão, o que, por consequência, altera o processamento, o armazenamento e a recuperação das informações.

Assim, as diferentes condições sensoriais, linguísticas, de vida quotidiana e de cultura, presentes não só na surdocegueira, mas em qualquer situação de vulnerabilidade sensorial, social e linguística, interferem nos processos de aquisição ou de aprendizagem da linguagem, bem como no pensamento, uma vez que o desenvolvimento cognitivo depende do domínio dos signos criados pela sociedade entre os quais se inclui a estrutura conceitual, motivadora da linguagem e do sistema de números, entre outros.

Ao discutir o processo de desenvolvimento da pessoa com surdez congênita, Sacks defende que o estímulo presente nas interações sociais precisa estar direcionada para a percepção visual, uma vez que a percepção auditiva possui uma barreira 
fisiológica que impede o acesso aos dados do contexto. $\mathrm{O}$ autor pondera que a surdez congênita gera riscos no processo de desenvolvimento, quando afirma que

\footnotetext{
Nem a linguagem nem as formas superiores de desenvolvimento cerebral ocorrem espontaneamente; dependem da exposição à linguagem, comunicação e uso adequado dessa linguagem. Se as crianças surdas não são expostas bem cedo à boa comunicação, pode haver um atraso (até mesmo uma interrupção) da maturação cerebral, com uma continua predominância do hemisfério direito e uma falta de transferência hemisférica. (SACKS, 1990, p. 128)
}

O autor levanta uma discussão sobre a importância da exposição da pessoa surda ou surdocega ao sistema de comunicação eficiente, em que a língua esteja em funcionamento, fato que viabiliza a manipulação interna e a construção do processo de autorregulação e de simbolização do mundo. Este processo deve acontecer o mais cedo possível, caso contrário pode gerar incompetência linguística e estender-se do linguístico ao cognitivo/intelectual.

Assim sendo, a questão do contexto linguístico em condições sensoriais específicas, como a surdocegueira, é um desafio que se coloca para o atendimento educacional especializado-AEE, conforme o Decreto Federal 7.611, de 17 de novembro de 2011. O primeiro desafio consiste em estabelecer uma interação com o surdocego e propiciar condições para que ele tenha consciência do papel da comunicação no ambiente. Nesse contexto, as formas de expressão linguística, com base no signo linguístico na área da surdocegueira, podem ser classificadas em três modalidades: 1tátil/sistema háptico, pele e cinestesia - Libras Háptica, datilologia tátil, Tadoma, braille para leitura e escrita, braille tátil, escrita caixa alta em espaços definidos pelo surdocego; 2- vísuo-motora, que é a Libras realizada no campo visual do surdocego; 3 oral-auditiva, o que corresponde à fala e à utilização de Aparelho de Amplificação Sonora Individual-AASI.

A metodologia que usamos neste artigo segue dois procedimentos enumerados: i) descrição, de modo breve, das possibilidades de expressão linguística dos surdocegos, segundo o perfil sensorial e linguístico, proposto por Cader-Nascimento (2016), qual seja, surdocego total com expressão linguística háptica - $\mathrm{SCtH}$; surdocego parcial usuário de língua de sinais - SCpLS; surdocego parcial usuário de fala e língua de sinais - SCpFLS; surdocego parcial usuário da fala e ampliação - SCpFA; ii) descrição da forma de expressão linguística, com trechos comentados de textos produzidos por SCtH, 
SCpLS, SCpFLS, SCpFA, uma vez que, para esses estudantes, o primeiro passo, no processo de desenvolvimento humano, é aprender uma língua ${ }^{1}$, segundo suas condições de acesso, quais sejam, visão, sistema háptico, audição, tendo em vista que a língua natural $^{2}$ não coincide com a língua materna ${ }^{3}$. Assim, o passo inicial considera que os estudantes aprendem primeiramente um sistema abstrato de comunicação e, na sequência, são direcionados à aprendizagem da língua portuguesa como segunda língua. A primeira língua pode ser a língua de sinais, a fala, a língua de sinais háptica, enquanto a segunda língua será o português na modalidade escrita. Demonstraremos a forma de expressão linguística, por meio de modelos da produção escrita, com sucinta análise da enunciação.

\section{Forma de expressão linguística na modalidade do sistema háptico}

Surdocegos pré-linguísticos, sejam eles surdocegos totais usuários da língua de sinais háptica (doravante $\mathrm{SCtH}$ ), sejam surdocegos parciais, usuários da língua de sinais em campo reduzido ${ }^{4}$ (SCpLS), fazem uso do sistema háptico na interação com o ambiente físico e humano. O input da modalidade tátil (sistema háptico) consiste na mudança do sistema de transmissão do ouvido e da visão para a pele e pela cinestesia. $\mathrm{O}$ sistema háptico, segundo Schiffman (2005, p.313):

[...] é responsável pela percepção das propriedades geométricas - formas, dimensões e proporções dos objetos manipulados [...] é capaz de apreender as propriedades geométricas dos objetos, como também de fornecer informações sobre seu peso e consistência. [...] o reconhecimento preciso de um objeto pode ser resultante apenas de um breve encontro tátil. [...] os inputs cinestésicos e cutâneo se combinam para atuar como um único sistema perceptual funcional.

As interações precisam estar voltadas para as mãos, pois são estas que irão realizar a leitura das expressões faciais dos parceiros de comunicação. São as mãos que participam do processo de exploração das "coisas", que realizam a leitura tátil, que imitam as configurações relativas à datilologia e aos sinais; são as mãos que entram em

\footnotetext{
${ }^{1}$ Língua. Sistema abstrato de signos inter-relacionados, de natureza social e psíquica, obrigatório para todos os membros de uma comunidade linguística. (FAULSTICH, 2016, p.6)

${ }^{2}$ Língua natural, consiste no processo de aprendizagem natural de um "sistema abstrato de signos interrelacionados, de natureza social e psíquica”. (FAULSTICH, 2016, p.6)

3 “....] língua materna como um conceito dinâmico que varia conforme um conjunto de traços relevantes, válidos para um determinado momento da vida do falante, os quais englobam a) a primeira língua aprendida pelo falante, b/ em alguns casos, simultaneamente com outra língua, com a qual compartilha usos e funções específicas, c/ apresentando-se porém geralmente como língua dominante, d/ fortemente identificada com a língua da mãe e do pai, e, por isso, e/ provida de um valor afetivo próprio." (ALTENHOFEN, 2002, p.15)

${ }^{4}$ A funcionalidade visual em surdocegos que determinará o processo de comunicação háptica ou não.
} 
contato com os movimentos realizados na produção da fala. Nesse contexto, toda criança, desde a educação infantil, e, se possível antes, na educação precoce, precisa entrar em contato com os signos linguísticos, ou alfabéticos, ou sinalizados. Os símbolos e os signos precisam estar integrados a um sistema de comunicação com estrutura sintática, morfológica, semântica e pragmática própria.

Os sistemas linguísticos para os SCtH e SCpLS, que podem ser estimulados, consistem na adaptação da recepção dos signos veiculados pela fala, pela datilologia, pela língua de sinais e pela escrita na modalidade tátil, que é o sistema háptico. Entre todos, o sistema háptico é a via mais promissora para a aprendizagem da comunicação receptiva e expressiva na área da surdocegueira pré-linguística; os sistemas vinculados à modalidade háptica são o Tadoma, a datilologia, a língua de sinais, o código braille, o código braille na interação com o outro, a escrita alfabética na palma da mão ou em uma superfície plana.

As formas de expressão na modalidade vísuo-motora para os SCpFLS e SCpLS são a língua de sinais e a escrita ampliada. Faremos breve descrição tanto do sistema háptico quanto da forma de expressão linguística na modalidade oral-auditiva, relativa à amplificação da fala. Ressaltamos, contudo, que, neste estudo, estamos privilegiando as formas de comunicação pela linguagem com base no signo linguístico, por isso não falaremos das formas de comunicação alternativa, pautada no uso de figuras, objetos, gestos naturais/domésticos, entre outros.

\section{Aprendizagem da fala na modalidade háptica: Tadoma}

O Tadoma é um recurso destinado aos SCtH, SCpLS, SCpFLS, SCpFA e deve ser introduzido com o objetivo básico de promover situações em que o surdocego possa acompanhar o diálogo entre dois parceiros de comunicação. Assim, a fala pode ser estimulada mediante a técnica conhecida como Tadoma ou "método de vibração". A aquisição ocorre mediante o canal perceptual háptico, porque envolve a pele e a cinestesia das vibrações durante o ato da fala. O processo de recepção das informações se dá pelo posicionamento da mão do surdocego na região do rosto (boca, lábios, queixo, pescoço e face) do parceiro de comunicação. A configuração da mão varia de pessoa para pessoa; alguns surdocegos utilizam as duas mãos na face do interlocutor, outros utilizam uma mão com configuração em B e outros em L. O processo de 
aprendizagem é lento e depende da exposição intensiva à experiência de interação que viabilize e reforce este comportamento. A técnica foi utilizada por Helen Keller (1939, p. 77) e segundo ela:

O tacto era o único recurso para ler os lábios de minha mestra. Pelo tato, apenas, tinha de aperceber-me do movimento dos lábios, da vibração da garganta e da expressão do rosto dela. Não raro esse recurso era impotente. Eu me via na contingência de ficar horas inteiras, repetindo a mesma palavra, até que ela fosse inteligível. Era preciso exercitar-me assiduamente e sem desânimo.

Consideramos, hoje, a técnica válida para bebês cegos e surdocegos, principalmente, para o estabelecimento dos padrões de comunicação precoce, préverbal. O Tadoma é uma técnica que viabiliza o desenvolvimento da percepção do som em cegos e percepção da vibração em surdocegos; produção da fala em cegos e surdocegos que percebem os movimentos de articulação da fala. Além disso, é possível leva-los à leitura das expressões faciais, à compreensão da articulação da boca e à emissão de fonemas. O desenvolvimento da consciência resulta de um processo de troca de turnos entre duas pessoas que utilizam a mesma modalidade de expressão linguística, no caso, a fala.

Não consideramos viável insistir neste sistema de comunicação para os SCtH, nem para os SCpLS, na adolescência ou na maturidade, uma vez que exige muita concentração e treino artificial de emissão e produção dos sons. Porém, é possível encontrar os SCtH pós-linguísticos que aprenderam o Tadoma aos sete anos de idade por iniciativa própria e o utilizam como um dos recursos de comunicação receptiva. Acreditamos, em função da nossa experiência, que o processo de aquisição de uma língua precisa levar em consideração o acesso à língua natural, sem barreiras fisiológicas para sua manifestação expressiva e receptiva.

Como a técnica do Tadoma tem por objetivo o ensino da fala, caso uma criança com surdocegueira venha a utilizar este recurso de comunicação, o acesso à língua portuguesa como segunda língua será por meio de textos ampliados com tamanho de fonte variando entre 14 a 18 ou superampliação com fonte acima de 24 , ou ainda, pelo código braille para leitura e escrita. Para ilustração neste trabalho, não conseguimos nenhuma produção escrita de pessoas com surdocegueira que utilizam o Tadoma. No ensino em Brasília, o Tadoma é utilizado inicialmente como sistema de comunicação 
para desenvolver a consciência da troca de turnos na comunicação, consciência da expressão facial e produção da fala.

\section{Datilologia na modalidade háptica}

De acordo com Castro Júnior, a datilologia consiste em um "processo linguístico em que o alfabeto manual é usado para expressar nomes de pessoas, de localidades, termos de outras línguas e termos do português que ainda não apresentam um sinal correspondente na LSB.” (CASTRO JÚNIOR, 2011, p. 22). É, portanto, soletração manual do alfabeto por meio de caracteres datilológicos correspondentes aos grafemas da língua oral e são utilizados para designar certo significado que não tem um sinal ou um sinal-termo próprio. Sinal-termo, criação de Faulstich, é definido como "sinaltermo, criado na LSB, para representar conceitos que denotem palavras simples, compostas, símbolos ou fórmulas, usados nas áreas específicas do conhecimento." (FAULSTICH, 2012).

Para isso, é utilizada a soletração digital das letras da palavra em evidência, como os nomes de pessoas. No caso do surdocego $\mathrm{SCtH}$, esta soletração ocorre no espaço e é captada por meio do sistema háptico, com o posicionamento da mão do surdocego em cima da mão do parceiro de comunicação. Ressaltamos que a datilologia na surdocegueira não se restringe à soletração de algumas palavras, em alguns casos, constitui-se no sistema de comunicação utilizado pelo surdocego para receber informações do ambiente e manter interações. Este recurso segue a estrutura da língua de modalidade oral-auditiva. Pode ser utilizada nos programas de educação precoce ao ensino superior. No caso de SCpLS, a soletração é realizada dentro do campo visual da pessoa surdocega, seja este campo visual central (visão residual central), periférico, superior ou inferior. A adaptação é realizada pelo próprio SCpLS que se posiciona para receber a informação segundo suas condições perceptuais de recepção do input pela via visual.

O ensino da datilologia na surdocegueira consiste na realização da leitura tátil da configuração de mão. Inicialmente, é possível a utilização de luvas com textura distinta para facilitar a indicação do modelo. A habilidade de recepção da informação pelo sistema háptico dá-se pela configuração da letra e, por meio do movimento coativo (mão sobre mão), orienta a criança a realizar o rastreamento da configuração de mão e a 
repeti-la. Na educação precoce, o processo pode-se iniciar com a letra do nome inicial da criança e da professora. Posteriormente, pode-se ampliar para o nome do cuidador que se faz presente nos atendimentos; muitas vezes, é necessário associar a letra a um elemento que seja referência à pessoa (cheiro, cabelo, brinco, colar, pulseira). Após rastrear a configuração da mão referente à letra, a criança necessita estabelecer a correspondência da letra à pessoa, e, imediatamente, deve-se conduzir a mão da criança para o ponto de referência que não poderá mudar durante os atendimentos, uma vez que todo este processo é para que a criança possa identificar quem é a pessoa. Esta orientação precisa ser aplicada no universo do lar pelo cuidador com todos os membros do grupo familiar, pois assim amplia e diversifica o tempo de exposição da criança a esta modalidade de comunicação. Quando a criança compreender toda a dinâmica e apresentar movimentos de antecipação em relação à atividade, pode ser iniciada a soletração de todo o nome.

Keller (1939), que era SCtH, aprendeu a datilologia como principal forma de expressão e recepção linguística, conforme consta no relato:

\footnotetext{
Quem lê para mim ou conversa comigo, vai compondo as palavras fazendo as letras com as mãos, segundo este alfabeto. Eu ponho a mão na sua, muito de leve, para não impedir os movimentos. Com o tato percebem-se as diferentes posições da mão, do mesmo modo que com a vista. Não sinto as letras em separado, mas agrupamento em palavras, tal como toda a gente que lê com os olhos. A prática traz notável agilidade aos dedos (KELLER, 1939 p. 78).
}

Esta é uma técnica bastante presente na comunicação com pessoas $\mathrm{SCtH}$, SCpFLS e SCpLS pré-linguísticos e pós-linguísticos. No caso das pessoas cegas que ficaram surdas, geralmente, há preferência por sistemas alfabéticos nas interações sociais, entre eles a datilologia e a escrita em superfície plana ou o código braille háptico como forma de comunicação receptiva. Como a datilologia segue a estrutura oral-auditiva, o processo de aquisição da língua portuguesa é correspondente à escrita de qualquer pessoa usuária da modalidade oral-auditiva.

Analisaremos, mais adiante, a produção escrita de um SCtH pós-linguístico, com primeira manifestação à cegueira, depois veio a deficiência física e, posteriormente, a surdez profunda. $\mathrm{O}$ surdocego $(\mathrm{SCtH})$ faz uso do dispositivo eletrônico conhecido como display Braille ou linha braille cuja função consiste em passar as informações do computador para o código braille. Quando o estudante perdeu a audição, encontrava-se no $6^{\circ}$. ano do ensino fundamental, período em que foi introduzido ao braille digital, à 
datilologia háptica e à escrita em uma superfície plana. No contato entre o guiaintérprete e o estudante, prevalecia a comunicação por meio da datilologia e do sistema braille.

Quadro 1 - Trecho de texto de Surdocego total háptico Braille - SCtH

professora,

A senhora esqueceu de mim. Nem liga para mim.

Como vão as coisas? Namorando muito? Deve estar, pois nem dá notícias. Bem, um pedido: um DB meu vai para a garantia. Nisso, talvez seria bom tentar pegar aquele grandão do CEEDV ou algo do tipo, ou algum outro que eu tenha que instalar. Aí, eu instalo, testo e configuro a tabela de caracteres e tal já mando com instruções de configuração e tal.

Tente fazer isso.

Abraços,

Essa produção escrita do $\mathrm{SCtH}$, usuário do código braille na leitura e na escrita, da datilologia ou escrita em superfície plana, o texto apresenta senso de humor. SCtH brinca com as ideias e as transmite em palavras. O texto demonstra um domínio da língua portuguesa, com estrutura SVO - sujeito, verbo e objeto: A senhora esqueceu de mim. Nem liga pra mim. O trecho tem enunciados curtos e outros longos, com vocabulário diversificado e coloquial (gíria, brincadeira). Apresenta uso de artigos definidos e indefinidos: $a$, as, o, um; de pronome indefinido: algum; preposições: $d e$, para; advérbios: talvez, muito; conjunções: pois, nem, com, de forma a relacionar, assim, as categorias na frase. O uso de pronomes pessoais mim, meu, eu está de acordo com a estrutura textual. É possível identificar no trecho analisado a concordância verbal. O autor tem conhecimento de que o sujeito é o elemento com o qual o verbo concorda, fato de morfossintaxe demonstrado pelo uso do paradigma flexional da variante padrão: A Senhora esqueceu [...] Nem liga [...]. Apresenta a noção de sujeito em elipse: já mando e utiliza o mesmo recurso em diversas passagens do trecho analisado.

$\mathrm{O}$ fato de o estudante ter na leitura e no sistema alfabético sua fonte de informação faz com que ele esteja exposto ao contato com a língua portuguesa na modalidade escrita, o que possibilita a ampliação do vocabulário e o acesso à estrutura do registro escrito. No entanto, o trecho em análise não explicita a estrutura textual de pedido ou solicitação, aspecto que precisaria ser abordado no ensino de português como segunda língua. 


\section{Língua de sinais na modalidade háptica}

A língua de sinais constitui-se em unidades convencionais integradas a um sistema de signos linguísticos articulados e, também, convencionais, de modalidade vísuo-espacial, utilizados por pessoas surdas e surdocegas SCtH, SCpLS e SCpFLS para transmitir ideias e sentimentos em campo espacial-visual específico. É uma língua que não depende de representação acústica, mas da articulação, configuração das mãos, do movimento no espaço de sinalização, do local de articulação, da orientação da mão no espaço combinado com a expressão facial. O processo é o mesmo na surdocegueira, só que o SCtH e, muitas vezes, o SCpLS necessitam posicionar a mão levemente na mão do interlocutor para que possa acessar os signos linguísticos. A distinção do recurso linguístico centra-se na recepção da informação, pois o surdocego necessita posicionar sua mão em cima da mão do parceiro de comunicação. Assim, realiza a leitura háptica da informação veiculada pelos signos linguísticos próprios da língua. Quando o diálogo se dá entre duas pessoas surdocegas totais, usuárias de língua de sinais, há uma alternância na posição da mão. Para receber a informação, a mão fica em cima; para emitir a informação, a mão fica embaixo da mão do parceiro de comunicação. Quando a interação ocorre entre um surdo e um SCtH, a manifestação comportamental na recepção da informação pelo surdocego ocorre pelo contato direto, porém, ao expressarse, o surdocego emprega a língua de sinais no espaço de sinalização, como qualquer outro usuário da língua de sinais.

$\mathrm{O}$ registro escrito de $\mathrm{SCtH}$, que faz uso da modalidade da língua de sinais háptica na comunicação, apresenta características próximas ao texto escrito de pessoas surdas usuárias da Libras. O quadro 2 exemplifica um trecho de texto escrito por uma estudante SCtH, pré-linguística que nasceu com surdez profunda bilateral, associada ao glaucoma de ângulo fechado, levando a perda visual aos 3 anos de idade do olho direito e baixa visão no olho esquerdo; neste caso, possuía percepção visual mediante a aproximação do objeto a $10 \mathrm{~cm}$ do olho funcional, no caso da escrita, a fonte perceptível era 72, negrito, espaço duplo. Até os 7 anos, não tinha acesso a qualquer língua. Iniciou os contatos e a exposição à Libras aos 8 anos de idade; atualmente, faz uso da Língua de Sinais Háptica na comunicação receptiva e da Libras na comunicação expressiva. Atualmente, encontra-se matriculada no ensino médio, com acompanhamento de 
professora na função de guia-intérprete ${ }^{5}$. O trecho selecionado para analise refere-se à manifestação da estudante a respeito da importância de um recurso de tecnologia assistiva no acesso à informação, conforme podemos observar no quadro 2.

Quadro 2 - Trecho de texto de Surdocego total háptico língua de sinais e braille - SCtH Eu preciso muito da linha Braille/ (nome da aluna) triste vida difícil/ Surda-cega e muito importante para vida Surda-cega à linha Braille/ Obrigada pela atenção ok. Brasília.

Ressaltamos que o texto do quadro 2 foi escrito no código Braille e entregue para a pesquisadora, nos primeiros momentos em que a estudante conhece o equipamento denominado de linha braille ou display braille ${ }^{6}$.

A análise do texto permite identificar o predomínio de sentenças curtas, com orações simples de estrutura sintática SVO: Eu preciso muito da linha Braille. Há no texto, formas flexionadas: Eu preciso / Surda-cega é; ausência de verbo de ligação "estar" na frase (nome da surdocega), triste, vida difícil; conflito no emprego da conjunção "e" "é" (verbo "ser"), na frase Surda-cega e muito importante para vida Surda-cega à linha Braille. Nesta frase, aparece o registro da palavra Surda-cega e Braille com iniciais maiúsculas, provavelmente, por se referir a uma pessoa específica; há emprego satisfatório de preposição e de advérbio no período analisado. A estrutura semântica é coerente, com trechos construídos por meio de uma sucessão de sentenças completas, porém curtas, com o uso de pronome na primeira pessoa Eu. A autora também emprega o nome próprio, que omitimos aqui.

O trecho do texto da $\mathrm{SCtH}$, que está no quadro 2, usuária da Língua de Sinais Háptica, apresenta características semelhantes ao texto produzido por surdos em processo de aquisição da língua portuguesa como segunda língua. O texto é fragmentado, porque os elementos verbais, as preposições, os determinantes e os articuladores lógicos ora aparecem, ora não. Contudo é um texto coerente. A comunicação se faz por causa da escolha do léxico e da repetição. Cabe ressaltar que o texto diz a mesma coisa de duas maneiras diferentes: "Eu (nome da aluna) preciso muito da linha Braille" E "e (É) muito importante para (a) vida (da) Surda-cega à linha

\footnotetext{
${ }^{5}$ Guia-intérprete é o profissional que orienta e contribui com o processo de mobilidade da pessoa surdocega nos espaços sócio-culturais, viabiliza a tradução da língua fonte para a língua alvo, bem com descreve o ambiente e os acontecimentos do ambiente físico e humano no qual a pessoa surdocega está localizada, conforme Dorado (2004).

${ }^{6}$ O Display Braille é um recurso de tecnologia assistiva de alto custo, com porta USB, que conecta-se ao computador e transfere todas as informações da tela para o código braille, bem como permite a comunicação por meio do registro escrito entre duas pessoas.
} 
Braille". Isso demonstra certa habilidade de argumentação pelo emprego do advérbio e do adjetivo.

No trecho do quadro 2, observamos que a estudante busca seguir a estrutura SVO e consegue organizar e utilizar o recurso da escrita como um meio de comunicação expressiva com o outro, no sentido de transmitir a ideia: a necessidade do equipamento para sua vida acadêmica e social.

\section{Código braile}

O código braille, criado em 1825, na França, por Louis Braille, é universal. É um código de leitura e escrita que tem por base a Cela Braille. Esta Cela é formada pela combinação de seis pontos dispostos em duas colunas paralelas, isto é, uma matriz de base 3 X 2, que sobressai do papel. Nesta estrutura são geradas 63 combinações que viabilizam a leitura-escrita braille por parte dos cegos e surdocegos. Em termos de registro escrito, segue os padrões da língua do país, bem como permite o registro de notações específicas de química, física, biologia, matemática e de pautas de músicas.

A aprendizagem do código Braille exige concentração e atenção, orientação espacial a aspectos sutis da escrita e leitura, requer habilidade cognitiva e uma percepção tátil bem desenvolvida. No caso de surdocegos, o processo da aprendizagem envolve a repetição das letras no código a partir da memorização dos pontos correspondentes, marcação dos pontos no espaço por meio da sequência de números. Assim, a letra /a/ corresponde ao ponto 1. Ao aprender a letra /a/, o surdocego marca o número 1 com a datilologia na parte superior, à esquerda na cela espacial, depois transfere o registro espacial para o papel. Alguns estudantes realizam a marca datilológica, depois a referente ao braille tátil para, na sequência, realizar o registro no papel. Na leitura do Braille, o aprendiz surdocego faz o contato com o ponto no papel, estabelece a correspondência com a datilologia na cela braille delimitada no espaço retangular localizado no lado esquerdo entre a região da cabeça e do ombro. Neste espaço, os pontos 1, 2 e 3 são registrados no alinhamento esquerdo da cela, enquanto os pontos 4,5 e 6 são alinhados na cela espacial à direita. Desta forma, o ponto 1 é marcado pelo algarismo de quantidade da Libras na altura da testa, o ponto 2 no alinhamento do nariz e o ponto 3 no região do queixo, sendo a letra marcada na região do peito. Assim, ao ler uma letra, sílaba, palavra, frase, oração, texto, o surdocego 
desliza o dedo indicador, geralmente da mão direita, levemente sobre as linhas escritas, por meio de movimentos horizontais, sagitais e de pressão identifica os pontos e estabelece o correspondente na datilologia com a mão esquerda.

- Código braille na interação com o outro

O braille tátil possui a mesma estrutura e o signo gerador do código braille utilizado na leitura e na escrita. Compõe-se de uma cela e seis pontos, com a diferença de que, ao se tornar tátil, passa a ser realizado pelo toque no corpo da pessoa, mas o registro é realizado segundo o padrão de leitura da esquerda para a direita.

O processo de aquisição do código braille tátil pode começar na infância como uma brincadeira e pode contribuir com a aprendizagem do código para leitura e escrita. Assim, braille tátil pode ser introduzido marcando no lado esquerdo o ponto 1 na cabeça, ponto 2 no ombro e o ponto 3 na cintura e os demais pontos 4 , 5 e 6 são realizados no lado direito do receptor. O processo de ensino do braille tátil começa em pontos amplos e, gradualmente, pode ser reduzido a toques nos braços. Começa-se no lado esquerdo do receptor sendo os pontos 1 - ombro; 2 - cotovelo; e, 3 - punho; os pontos 4, 5 e 6 nos mesmos locais do lado direito do corpo. Outra forma do braille tátil consiste na marcação dos pontos nas falanges dos dedos. Assim, tendo a mão configurada na letra " $U$ " da datilologia, começa do lado esquerdo do receptor e, no dedo do meio, marca-se os pontos 1, 2 e 3 (cada ponto em cada falange) e, no dedo indicador, os pontos 4, 5 e 6 . A orientação é sempre a da leitura para quem está recebendo a informação.

Outra técnica consiste na representação dos dedos como se fosse realizar o uso da máquina braille modelo Perkins. Assim, o receptor posiciona, em uma superfície plana, os dedos anelar (pontos 3 e 6), dedos do meio (pontos 2 e 5) e indicadores (pontos 1 e 4) das mão direita e esquerda, representando as teclas da máquina braille. $\mathrm{O}$ parceiro de comunicação se posiciona na frente do interlocutor e começa a tocar cada dedo, formando as letras correspondentes à expressão. Esta modalidade de comunicação ocorre por meio da soletração de cada letra para formar a palavra e geralmente é utilizado por surdocegos na interação com cegos, ou com pessoas que só dominam o código braille. A Figura 3 exemplifica a soletração de uma palavra por meio do braille tátil. 


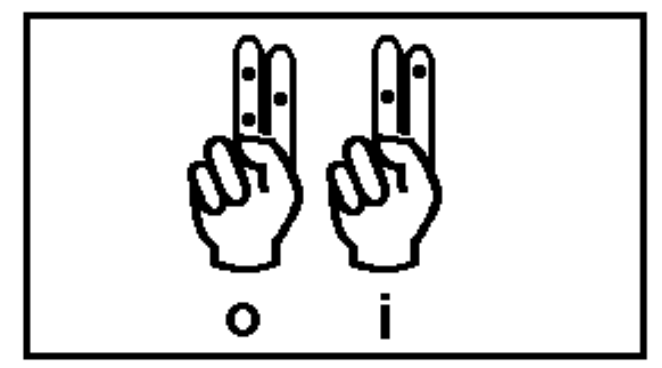

Fonte: (CADER-NASCIMENTO, 2004).

Os surdocegos $\mathrm{SCpF}$, usuários do código braille digital/tatil na comunicação receptiva, apresentam um texto com a estrutura de sujeito, verbo e objeto - SVO, conforme consta no exemplo presente do SCpF, usuário do Braille, AASI, em e-mail:

Quadro 3 - Trecho de texto de Surdocego parcial fala braille - SCpF

Eu passei a trabalhar 11 anos depois que eu terminei o ensino médio, em 2004. Professora, a pessoa tem que desenvolver uma força de vontade muito grande, pois enquanto a gente não mostra que é a capaz a nossa imagem diante a sociedade é de coitadinho." (sic, SCpF, por e-mail).

O trecho referente à produção escrita do $\mathrm{SCpF}$, usuário de AASI e código Braille na leitura e na escrita, apresenta um domínio da língua portuguesa. $\mathrm{O}$ registro segue a estrutura SVO - sujeito, verbo e objeto, como podemos observar no trecho, que também apresenta enunciados longos, o que é distinto da característica da escrita do SCtH ou SCpLS, cujos enunciados são curtos com vocabulário reduzido. O texto apresenta uso de artigos definidos e indefinidos: a, o, uma; preposição: de; advérbio: diante, depois, muito; conjunção: pois, enquanto. Há forma flexionada do verbo. O uso de pronomes demonstra que o referente se flexiona com o verbo. É possível identificar no trecho que o estudante $\mathrm{SCpF}$ apresenta concordância verbal na primeira pessoa. Sabe que o sujeito é o elemento com o qual o verbo concorda, o que evidencia que o estudante faz uso do paradigma flexional da variante padrão: Eu passei [...] Eu terminei [...]. A ausência do feedback visual ou tátil, ou ainda, a compreensão parcial da leitura mecânica, realizado pelo programa sintetizador de voz, interfere na revisão do texto escrito pelo próprio autor. Porém, a presença de determinantes, pronomes e articuladores lógicos indica um texto coeso. A presença de elementos coesivos, adequadamente empregados em um texto, contribui para a construção da coerência textual. 


\section{Escrita alfabética em superfície plana}

Este processo de comunicação consiste no registro das letras em caixa alta (maiúsculas) do alfabeto romano na palma da mão do surdocego, ou em uma superfície plana. É feito com o dedo indicador, nos movimentos necessários para o registro de cada letra que compõe a palavra, conforme mostra a Figura 2

Figura 2 - A escrita na mão

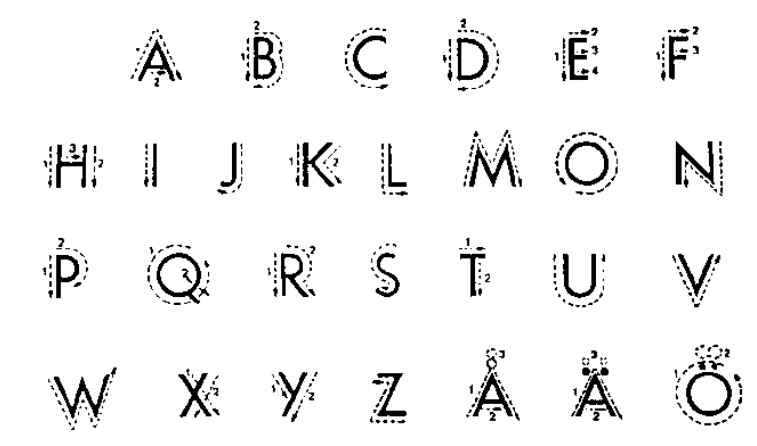

Fonte: (International Standard Manual Alphabet)

\subsection{Forma de expressão linguística na modalidade vísuo-motora: língua de sinais}

A língua de sinais é utilizada pelos surdocegos pós-linguísticos que manifestaram primeiro a surdez. Ao manifestar a retinose pigmentar ou outra doença que leva à degeneração do sistema visual, o surdocego cria estratégias para continuar estabelecendo trocas interativas por meio da língua de sinais.

Na nova condição sensorial, o surdocego estabelece a distância que precisa ficar do interlocutor para que possa ter acesso às informações. O espaço de sinalização é determinado pela eficiência do funcionamento visual do surdocego, por isso cabe à própria pessoa dizer a distância e o melhor espaço para sinalização. Assim, o espaço e o ritmo da soletração datilológica, do sinal, signo linguístico da Libras, é alterado em função do campo de visão.

Forma de expressão linguística na modalidade oral-auditiva

A modalidade oral-auditiva é um recurso de comunicação, viabilizado ao surdocego mediante o uso do Aparelho de Amplificação Sonora Individual (AASI), com vistas a ganhos auditivos. Para isso, o mediador deverá falar devagar e de forma clara, de preferência em um local tranquilo sem muito barulho ou ruído, pois o AASI 
amplia todos os sons do ambiente, o que pode incomodar e irritar o aprendiz.

A produção escrita do $\mathrm{SCpF}$, no caso ilustrado a seguir, é de um estudante cego com surdez severa e que faz uso cotidiano do Aparelho de Amplificação Sonora Individual e fala ampliada, próximo ao ouvido. Consegue, assim, estabelecer relações sociais por meio de redes sociais, whatsapp, bem como consegue falar e ouvir ligações telefônicas. Faz pouco uso da leitura e da escrita no cotidiano, já concluiu o ensino médio e, atualmente, é funcionário concursado do Governo do Distrito Federal - GDF.

\section{Quadro 4 - Trecho de texto de Surdocego parcial Fala - SCpF}

Olá bom-dia professora Fatima. E aí já está melhor/ tá tudo bem contigo /como estão as coisas /assim que puder me dê retorno / Fala para a Maria que eu quero conhece-lo e me passe o telefone dela/ falou que vou ligar para ela/ ok/ grande abraço (SCpF, Whatzapp)

É preciso observar, no trecho de produção escrita do SCpF, usuário da fala ampliada, que ele não utiliza o código Braille. O texto possui um domínio da língua portuguesa segundo a estrutura SVO completa - sujeito, verbo e objeto, pois o autor preenche a posição de sujeito e de objeto da sentença. O trecho aponta enunciados curtos e longos, distintos da característica da escrita do SCtH ou SCpLS, cujos enunciados são curtos com vocabulário reduzido. O texto mostra o uso de artigos definidos com flexão: $a, o$, as; da preposição: de; de expressão interrogativa: como; de pronomes pessoais: $e u$, ela; da combinação da preposição de +o pronome pessoal ela; estabelece concordância com o referente e usa a forma flexionada do verbo. Ao empregar os pronomes pessoais, demonstra bom uso dos pronomes oblíquos como complemento verbal. É possível identificar frases em que o estudante SCpF apresenta concordância verbal na terceira pessoa, assim como é possível constatar que usa a variante padrão: Eu quero conhece-lo / me passe o telefone dela. O sujeito em elipse está evidenciado no período analisado: E aí já está melhor. / falou que vou ligar para ela. Por outro lado, SCpF não faz uso de sinais de pontuação, talvez em função da ausência de feedback visual ou tátil, ou ainda, por causa da compreensão parcial da leitura mecânica realizada pelo programa sintetizador de voz, que interfere na revisão do texto escrito pelo próprio autor.

\subsection{Escrita ampliada}

Os SCpF pós-linguísticos, com surdez moderada e severa, associada à baixa 
visão, demandam o uso de textos ampliados, se possível na fonte Arial no tamanho que varia de 14 a 18, ou super-ampliação no tamanho de 20 a 24, conforme resultado de avaliação da funcionalidade visual. Muitos surdocegos precisam, além da ampliação, da presença de contraste. No caso da ampliação artesanal, utilizam-se letras caixa alta, com tamanho variando de 1 a $15 \mathrm{~cm}$. Antes de utilizar este recurso, é importante que o especialista conheça a eficiência visual, o prognóstico e a capacidade de discriminação visual do surdocego.

O texto do $\mathrm{SCpF}$ tem recursos ampliados de leitura e de escrita na fonte 16. Ele tem 19 anos e se encontra no $6^{\circ}$. ano do ensino fundamental. O estudante não faz uso de AASI; a fala é a forma de expressão e recepção das informações; realiza aproximação da fonte sonora e visual e utiliza letras caixa alta na escrita, em folha com pauta ampliada.

Quadro 5 - Trecho de texto de Surdocego parcial Fala ampliada - SCPF JOSÉ VOCÊ É MEU MELHOR AMIGO QUE A NOSA AMIZADE NÃO ACABE NUNCA/ QUE RO CER CEU AMIGO PARA SENPRE/ PENRRO DE VOCE ATE QUANDO EU NÃO TOR NA ESCOLA/ EM CASA FALO QUE DENHO UM AMIGAO ESPECIAL COMO VOCE / QUANDO CHEG FINAL DE CEMANA NÃO VEJO A HORA DE DA SEGUNDA FEIRA PARA BRINCAR COM VOCE/ PARA VOCE VER JOSÉ QUE VOCE E COMO UM IRMAO PARA MIN/ SUA AMISADE E INPORTANTI PARA NIN / VOE E O PREMEIRO AMI E O CEI QUE EU SO CEU PREMEIRO AMIGO ABRSO ACINADO

Neste trecho do SCpF, o estudante apresenta diversos erros ortográficos, marcados pela confusão do uso de "M" e "N": senpre/sempre, min/mim, inportanti/importante; "S"/“C"/SS: nosa/nossa, cer/ser, ceu/seu, penrro/penso, cemana/semana, voe/você, cei/sei, so/sou, abraso/abraço, acinado/assinado e ausência de sinais de pontuação. Provavelmente, a ausência do uso do AASI, a falta do ensino de português como segunda língua e do ensino das regras relativas à ortografia podem estar contribuindo para a perpetuação do registro com trocas, omissões e substituição de letras. Em termos de estrutura, há a presença de períodos completos com sujeito, verbo e objeto: José, você é meu melhor amigo, que a nossa amizade não acabe nunca. O estudante faz uso da língua escrita como um recurso de comunicação com o outro, portanto possui claramente a função social da escrita e consegue expressar o conteúdo semântico de forma clara, segundo a estrutura SVO da língua portuguesa na modalidade escrita.

As modalidades de expressão linguística, abordadas neste artigo, foram três: háptica, que é o processo de soletração manual das letras para formar palavras e frases; 
Libras háptica, Tadoma - percepção tátil da fala, modalidade vísuo-espacial, Libras em campo visual, soletração manual; e oral-auditiva, a fala ampliada. As formas de expressão linguística variam de indivíduo para indivíduo, porém todas elas possibilitam a mediação do processo de aprendizagem do português como segunda língua. Ressaltamos que os trechos de texto de surdocegos usuários da Libras háptica ou da Libras na modalidade vísuo-espacial estão próximos da produção escrita de surdos cuja modalidade de comunicação é a Libras. Assim sendo, percebemos, nas produções de português escrito, a interferência das duas línguas distintas que estão em contato: escrita e sinais. Contudo, “[...] apesar dos textos apresentarem problemas na forma, não terem violado o princípio da coerência [...] conseguem expressar de modo inteligível suas ideias" (SALLES et alii, 2004, p.35) No entanto, este processo só é possível mediante o atendimento em português como segunda língua, com ênfase voltada para responder a questões como, salientado em Salles et alii $(2004$, p. 25) “[...] por que este texto foi produzido? Para que ele serve? Para quem é dirigido? Enfim, qual a sua importância social? São questões relevantes que professor e aluno não podem perder de vista”. Além disso, é importante considerar que o meio de acesso aos materiais é o português escrito por meio do código braille ou da escrita ampliada em fonte 18 ou superampliada em fonte 24. Assim, a ausência do contato com a escrita braille ou ampliada promove lacunas no processo de uso desta ferramenta social.

No caso dos surdocegos que utilizam a modalidade oral-auditiva ou um sistema de comunicação com base na soletração manual ou no registro escrito em superfície, o contato com o texto escrito é fundamental. A ausência do contato com o registro escrito acarreta alterações na produção do texto escrito, entre elas questões vinculadas à ortografia. Este grupo também demanda por atendimento educacional especializado em português como segunda língua.

\section{Considerações finais}

O desenvolvimento da pesquisa nos permitiu aprofundar a modalidade espacial/háptica da língua utilizada por SCtH e SCpLS, porque evidenciou que o recurso linguístico não é restrito ao tato, mas é desenvolvido a partir de um sistema complexo de percepção háptica que envolve pele e sistema cinestésico. Mas do que isso, a pesquisa contribuiu para aprofundar a discussão do processo de aprendizagem da 
língua, com ponto de partida do concreto, da vivencia de situações cotidianas e funcionais em direção a um processo de abstração crescente.

Uma das nossas intenções foi demonstrar que, no escopo da Línguística, há recursos para que sejam identificadas "propriedades fundamentais das línguas humanas" (FRANÇA, FERRARI, MAIA, 2016, p. 15), além disso, França, Ferrari, Maia nos advertem para "uma reflexão sobre as cognições da visão e da audição para motivar a ideia de que há computações cerebrais mais gerais e outras mais específicas de cada cognição." (idem, ibidem).

Nessa direção, o estudo da surdocegueira abre um novo campo de investigação com vistas a novos dispositivos de acesso às línguas, em especial, à língua portuguesa na modalidade escrita, mediante a ausência total ou parcial dos sentidos distais, a visão e audição. Este é, de fato, um trabalho inicial que nos conduz a aprofundar a relação entre as formas de expressão linguística, inclusive a produção textual; é também uma motivação para que mais pesquisas sejam feitas na área. Certas de que o indivíduo surdocego precisa ser exposto ao uso da linguagem desde a infância, segundo as condições de acesso sensorial, defendemos a implementação de uma política linguística especializada que garanta a esse público os direitos sociais e civis.

De modo efetivo, os dados obtidos revelaram a importância da ampliação do contato das pessoas surdocegas com a diversidade de gêneros textuais para que possam ampliar vocabulário e apropriar-se de estruturas da língua escrita de forma acidental. Os trechos dos textos analisados expressam o uso da língua escrita como decorrente de uma atividade cognitiva interna dos sujeitos, na busca de estabelecer as relações de conhecimento internas - motivação intrínseca para o contato a distância - com a dinâmica dos processos externos e sociais de construção de sentidos. O ensino da língua portuguesa na modalidade escrita, com metodologia especializada, pode ser 0 diferencial para que o surdocego utilize o sistema linguístico de modo eficaz e adequado no exercício crítico, reflexivo e atuante da própria cidadania.

\section{REFERÊNCIAS}

ALTENHOFEN, C. V. O conceito de língua materna e suas implicações para o estudo do bilinguismo (alemão-português). In: MARTIUS, S.J. São Paulo, n. 49, p.141-161, 2002.

BRASIL, Decreto Federal 7611 de 17/11/2011. Dispõe sobre a educação especial, o 
atendimento educacional especializado e dá outras providencias. Disponível em https://www.planalto.gov.br Acesso em 7/7/2016

CADER-NASCIMENTO, Fatima A. A.A.; COSTA, M. da P. R. da. Descobrindo a surdocegueira: educação e comunicação. São Carlos: EDUFSCar, 2010.

CADER-NASCIMENTO, Fatima A.A.A. Aspectos linguísticos do estudante surdocego da rede pública de ensino do Distrito Federal. Monografia de Especialização em Ensino de Língua Portuguesa como segunda língua para estudantes surdos - PSL - LSB. Brasília: Departamento de Linguística, português e línguas clássicas - LIP, 2016.

CASTRO J. Gláucio de. Variação linguística em Língua de Sinais Brasileira: Foco no léxico. 2011. 123 f. Dissertação (Mestrado em Linguística) Programa de Pósgraduação em Linguística. Universidade de Brasília, Brasília.

DORADO, M. G. La guia-interpretación: aspectos fundamentales. In: VIÑAS, P.G.; REY, E.R.; (org). La sordoceguera. Um analisis multidisciplinar, Madrid: ONCE, 2004.

FAULSTICH, Enilde. Nota lexical. Sinal-termo. Disponível em http://www.centrolexterm.com.br, 2012. Acesso em 10/3/2016

FAULSTICH, E. Procedimentos básicos para glossário sistêmico de léxico terminológico: uma proposta para pesquisadores de língua de sinais. Inédito, em elaboração.

FRANÇA, A. I.; FERRARI, L. MAIA, M. A linguística no século XXI: convergências e divergências no estudo da linguagem. São Paulo, Contexto, 2016.

KELLER, H. A história de minha vida. Rio de Janeiro: Ed. José Olímpio, 1939.

KELLER, H. Lutando contra as trevas. 2 ed. Rio de Janeiro: Editora Fundo de Cultura S.A. 1961.

SACKS, O. Vendo vozes: uma jornada pelo mundo dos surdos. Rio de Janeiro: Imago, 1990.

SALLES, H. M.M. L. et al. Ensino de língua portuguesa para surdos: caminhos para a prática pedagógica. Brasília: MEC, SEESP, 2004

SCHIFFMAN, H. R. Sensação e percepção. Rio de Janeiro: LTC, 2005. 